\title{
Weak but persistent provenance effects modulate the response of Quercus robur (Fagaceae) seedlings to elevated temperature
}

\author{
Sumitra Dewan ${ }^{1 *}$, Pieter De Frenne ${ }^{1 *}$, Sebastian Kepfer-Rojas ${ }^{2}$, Safaa Wasof ${ }^{1}$, \\ Kristine Vander Mijnsbrugge ${ }^{3}$, Kris Verheyen ${ }^{1 *}$
}

${ }^{1}$ Forest \& Nature Lab, Department of Environment, Ghent University,

Geraardsbergsesteenweg 267, BE-9090 Gontrode, Belgium

${ }^{2}$ Department of Geosciences and Natural Resource Management, University of Copenhagen, Rolighedsvej 23, DK-1958 Copenhagen, Denmark

${ }^{3}$ Research Institute for Nature and Forest (INBO), Geraardsbergen, Belgium

Gaverstraat 4, BE-9500 Geraardsbergen, Belgium

*Authors for correspondence:

Email: dewansumitra@gmail.com, Kris.Verheyen@UGent.be and Pieter.DeFrenne@ugent.be 


\begin{abstract}
Background and aims

Clinal variation in bud phenology and growth has repeatedly been reported in common garden experiments for many tree species. The response of the seedlings generated from such translocated trees has not been studied yet, despite its relevance regarding the role of transgenerational plasticity in the adaptation of long-living trees in the face of climate change. Here, we aim to understand the effects of warming on bud burst, germination success and growth performance of tree seedlings of different origins (provenances) but that shared their maternal environment.
\end{abstract}

\title{
Methods
}

We collected seeds from a mature provenance trial of five different provenances of oak (Quercus robur, Fagaceae) and seeds were grown in two common gardens at two different latitudes representing a mean annual temperature difference of nearly $2{ }^{\circ} \mathrm{C}$ in Belgium and Denmark. We assessed seed germination, bud burst time and biomass of seedlings in two common gardens.

\section{Results}

We observed an interaction between provenances and common gardens in seedlings' bud burst time indicating the prevalence of an environmental effect at the site of origin (provenance), which depends on the seedlings' growing environment (across the two common gardens). The germination success and shoot biomass were reduced across all provenances in the southern common garden.

\section{Conclusions}

Our results indicate that the environment of origin influences the bud phenology of seedlings and this provenance effect is dependent on the seedlings' growing environment. In addition, our results suggest that the effect of warming might differ between provenances and that the environmental history of the previous generations is likely to influence the response of tree seedlings as well.

Key words: provenance, seedling, temperature, bud burst, common garden, germination, biomass 


\section{INTRODUCTION}

Global surface temperatures are increasing at a rate of circa $0.2^{\circ} \mathrm{C}$ per decade since the $1970 \mathrm{~s}$ (Hansen et al. 2006; IPCC 2013). The extent to which populations persist in a warming climate depends on the ability of plant populations to respond via migration, adaptive evolution, and phenotypic plasticity (Hoffmann \& Sgro 2011). The present velocity of species' migrations and adaptations in response to global warming is, for many species, too slow to cope with rapid climate change (Kullman 2002; Loarie et al. 2009; Delzon et al. 2013). This slow migration is especially true for long-lived organisms such as trees that also exhibit slow genetic adaptation (Aitken et al. 2008). On the other hand, intense gene flow in forest stands can provide lead to higher local fitness due to higher genetic diversity (Carvalho et al. 2010) unless when climatic stress is too high the effect of gene flow may be overruled by selective pressures (Borovics \& Mátyás 2013). In such extreme climatic conditions, mechanisms such as phenotypic plasticity may have the potential to help forest trees to cope with rapid climate change.

Phenotypic plasticity is defined as the range of phenotypes that a single genotype can express as a function of its environment (Bradshaw 1965; Nicotra et al. 2010). One form of phenotypic plasticity is known as transgenerational plasticity (TGP), in which the environment of earlier generations influences the offspring growth and its responses to environmental conditions independent from genetic changes (Beaman et al. 2016). TGP is known to have a positive influence on plant adaptation particularly during rapid shifts of climatic conditions (Kuijper \& Hoyle 2015). More and more evidence is accumulating that the parent plant's environment influences the performance of the offspring (Groot et al. 2016; Groot et al. 2017; Lampei et al. 2017; Munzbergova \& Hadincova 2017). Most TGP studies are on annuals and species with vegetative reproduction abilities (Galloway \& Etterson 2007; Latzel et al. 2014; Groot et al. 2017; Munzbergova \& Hadincova 2017). There are few studies on TGP in trees; mostly due to their long generation times (Raj et al. 2011; Borgman et al. 2014; Dewan et al. 2018). Nonetheless, TGP may be vital for tree adaptation, given that long-lived trees may be able to pass to their offspring, through their germ cells, epigenetic variations that were induced years earlier and had already been somatically tested (Herman \& Sultan 2011; Jablonka 2013).

Provenance trials or common garden experiments are traditionally used to study local adaptation assuming a higher fitness of dominant to co-dominant tree species at the home site in comparison to the translocated sites (Whitlock 2015). In such common garden experiments, populations often display clinal variation in bud burst and growth of different provenances along gradients of the temperature at their origin (Olson et al. 2013; Saenz-Romero et al. 2017; Wilkinson et al. 2017). It is likely that when the trees of such transplant experiments reproduce, some of the adaptive traits such as bud burst time, growth and survival are influenced not only by the environmental conditions of the seedling but also by the past environment of the mother plant. Studies focusing on the response of the offspring of translocated tree population in transplant experiments can reveal the possible role of transgenerational plasticity in evolutionary tree adaptation.

Many common garden experiments showed in situ patterns in bud burst, where trees originating from different geographic origins start flushing according to the temperature at their origin (Kremer 2016; Wilkinson et al. 2017). It is not known whether the progeny of such translocated individuals displays the provenance effect when the mother trees have been growing in a common environment for nearly half a century. In addition, we do not know how the seedlings of these translocated individuals of different provenances would respond in a warmer world.

Here we took advantage of an existing mature provenance trial of oak (Quercus robur) in Nyskov, Denmark, to study the responses of the offspring of five different oak provenances that 
have been growing for more than 50 years in a common environment (Jensen 2010). We sampled acorns in this provenance trial and replanted them at two different common gardens: one close to the maternal common garden (situated in Copenhagen, Denmark at $50 \mathrm{~km}$ from the maternal common garden) and the other one in Gontrode, Belgium. The latter represents a climate warming scenario $\left(+2^{\circ} \mathrm{C}\right.$ mean annual temperature) that is predicted to occur in Denmark by c. 2080 (Christensen et al. 2013).

Here we studied the provenance effects on the performance of second-generation seedlings. We also assessed the effects of warming on the responses of the seedlings of different provenances. In both gardens in Belgium and Denmark, we monitored germination, bud burst, and biomass of the seedlings for two years. We also followed the bud burst time of individual mother trees to compare the variability in bud burst time between mother trees and seedlings. We expected existing variability in bud burst time among different provenances in mother trees as well as in seedlings. The seedlings' bud burst time would likely advance with warming. Since bud burst trait controls the start of growing season, changing bud burst time would likely affect the growth of the seedlings with warming. Finally, we assumed that warming would affect the germination success of the acorns of different provenances. 


\section{MATERIALS AND METHODS}

\section{Study species}

European oak (Quercus robur) is widely distributed in Europe and also in Russia, The Caucasus, Iran, Kazakhstan and Turkey (Jones 1959; Kozharinov \& Borisov 2014). It can grow in areas with mean annual temperatures between $5^{\circ} \mathrm{C}$ to $13.9^{\circ} \mathrm{C}$ (Rozas 2005 ; Drobyshev et al. 2008). It is monoecious, wind pollinated (anemophilous). Individuals of Quercus species start to flower at the age of 15-35 years (Jones 1959; Johnson et al. 2002). In the open, seed production by mature trees occurs almost every year, while in dense forest stands, it occurs at intervals of 3 or 4 years (Wesołowski et al. 2014). Yet, years in which there is an almost complete failure of seed production are frequent (typical masting behaviour) (Wesołowski et al. 2014). Although birds or mammals disperse seeds, most are dropped below the parent tree.

\section{Study site and seed collection}

The oak (Quercus robur) provenance trial was located at Nyskov, Denmark (table 1) containing two Danish (Bregentved and Wedellsborg), one Swedish (Visingsö) and one Dutch (locality of this provenance is not known, see Jensen (2010)) provenance (appendix 1 in supplementary file). There were two replicate plots for the Bregentved provenance. We kept the plots separately and recognized them as Bregentved 1 and Bregentved 2, and counted them as separate provenance in this paper because the replicated plots may represent different genotypes. The provenance trial was established between 1940 and 1947 with the primary purpose to test the production and wood quality for tree breeding. We selected the mother trees such that the canopy was separated from the other trees and the acorns could easily be separately collected from a single mother tree. In November 2015, we collected circa 1200 acorns in total from the forest floor around the base of the stem of the mother trees. We selected healthy acorns based on the absence of insect damage, and only selected relatively large acorns. Four mother trees per provenance (except, only three mother trees in Bregentved 1) were selected, resulting in nineteen mother trees. The seeds were stored cold $\left(5^{\circ} \mathrm{C}\right)$ until sowing.

\section{Common garden and experimental design}

Within a few days following collection, we measured the fresh acorn mass of each acorn and sowed seeds at circa one $\mathrm{cm}$ depth in trays using standard potting soil (Peltracom, NPK 14:16:18). Each tray contained 28 cells and the dimension of each tray was 51 by $28 \mathrm{~cm}$ and 15 $\mathrm{cm}$ deep. The volume of each cell was circa $13.2 \mathrm{cc}$. We sowed one acorn per cell while we randomly distributed the provenances in each tray. In total, there were 41 trays (1171 seeds in total, see appendix 2 and 3 in supplementary file for more details), and we kept the trays for circa 56 days at the edge of a forest at Forest \& Nature Lab, Ghent University, Gontrode, Belgium (table 1). In December 2015, we transported half of the trays (21 in total) to the northern common garden at the University of Copenhagen, Denmark, located circa $50 \mathrm{~km}$ away from the provenance trial with the purpose to expose the seedlings to a similar climate as the mother trees (table 1). The remainder of the seed trays were kept at the southernmost garden in Belgium. The description of the provenance trial and common gardens can be found in table 1 and appendix 1 in supplementary file. Plants were protected from birds and rodents in both countries using a fence around, and a cage/net above the pots. We watered the plants twice per week in both common gardens except during rainy days.

Daily maximum and minimum temperatures and total daily precipitation for 2016 were obtained from the National Oceanic and Atmospheric Administration (NOAA) National Centers for Environmental Information (http://www.ncei.noaa.gov/) for the Danish common garden and weather station at Melle (www.kmi.be) for the Belgian common garden. In 2016, 
the mean annual temperature difference between two common gardens was $1.8^{\circ} \mathrm{C}$ (appendix 4 in supplementary file): the mean annual temperatures in the Belgian and Danish common garden were $11.1^{\circ} \mathrm{C}$ and $9.3^{\circ} \mathrm{C}$ respectively. In the same year, total precipitation was $1001 \mathrm{~mm}$ and $623 \mathrm{~mm}$ in the Belgian and Danish common garden respectively.

\section{Monitoring germination, bud burst and biomass}

We monitored seed germination (emergence of the shoot) twice a week between 5 April 2016 and 22 July 2016 in both common gardens, and germination percentage was quantified based on the number of seedlings emerged from sowed seeds. We measured the bud burst of the seedlings at both common gardens from 27 March 2017 until all the seedlings and mother trees had completely opened their buds (stage 3) (table 2). We scored the stages of bud burst once (Denmark) to twice (Belgium) per week following the adapted method of Wesołowski and Rowiński (2006) (table 2). For seedlings, bud burst was monitored on the apical bud of each seedling. For mother trees, each observation was ideally performed on ten apical buds on the southern, lowermost part of the crown. At the end of the experiment in August 2017, we harvested all seedlings and quantified the shoot biomass of each seedling in both common gardens after drying them in an oven at $70^{\circ} \mathrm{C}$ for 24 hours.

\section{Data analysis}

All data analyses were performed in $\mathrm{R}$ version 3.3.3 ( $\mathrm{R}$ Core Team 2017). We tested for the effects of provenances and warming on germination and bud burst of the seedlings. Since the parental environment can affect the seed mass (Roach \& Wulff 1987; Lacey et al. 1997), we included acorn mass as covariate (continuous fixed effect) in the analysis to control for its effects. We used Generalised Linear mixed effects models ( glmer function in the lme 4 package in R) with Binomial distributions for germination percentage and with Poisson error distributions for seedlings' bud burst time as a function of provenance, common garden and their interaction, and acorn mass (Bates et al. 2015). In both models for germination and bud burst, we used mother tree (individual ID) and Tray as non-nested random effects. To test for the effect of mother trees on bud burst, we also used Generalised Linear mixed effects models (glmer function in the lme4 package in R) with Poisson error distributions. Seedling bud burst time was modelled as a function of provenance, common garden and their interaction, mother tree (individual ID) and acorn mass using Tray as random effect. We calculated the number of days to bud burst of the seedlings from the starting of the observations (27 March). In addition, we used Linear mixed effects models (lmer function in the lme4 package in R) with Gaussian error distributions and mother tree (individual ID) as a random effect to assess the effect of provenance on acorn mass (Bates et al. 2015). Next, we assessed the effects of provenance, common garden and their interaction, and acorn mass on biomass, by using Linear mixed effects models (lmer function in the lme4 package in R) with Gaussian error distributions, and mother tree and Tray as non-nested random effects. The number of seedlings in different provenances and mother trees was not evenly distributed in the analysis of bud burst and biomass (appendix 2 in the supplementary file).

To test the overall effect of common garden, provenance and their interaction, and acorn mass on the germination, bud burst time and biomass we performed a likelihood ratio test. We used the full model including Common garden, Provenance, Acorn mass and interactions between Common garden and Provenance always with mother tree and Tray as non-nested random effects and compared it with the reduced model by dropping each variable and interaction term at a time to get the effect size of the variable in question. 
RESULTS

\section{Bud burst}

Seedlings of the Bregentved 2 and Wedellsborg provenances had delayed bud burst time compared to Bregentved 1 (table 3 ). We found a weak marginally significant effect of the provenance on the seedlings' bud burst time $\left(\chi^{2}=13.8, p=0.09\right.$ and table 4$)$. The effect of some mother trees was significant on the bud burst time of the seedlings (appendix 5 in the supplementary file). The seedlings displayed nearly four weeks earlier bud burst in the Belgian common garden than the Danish common garden (fig 1,2). Seedlings resulting from heavier acorns displayed earlier bud burst in both common gardens $(\mathrm{z}=-3.48, \mathrm{p}=<0.001$, table 3 , appendix 6 in the supplementary file).

\section{Germination percentage and acorn mass}

The probability of seed germination differed significantly between the two common gardens being lower in the Belgian common garden $(\mathrm{z}=2.31, \mathrm{p}=<0.05$, table $3 \&$ fig 3$)$. There was no significant difference in the probability of seed germination between the provenances $\left(\chi^{2}=\right.$ $10.9, p=0.21$, table 3 and table 4 ). We did not observe any difference in acorn mass among the provenances $(\mathrm{F}=1.80, \mathrm{p}=0.19$ and appendix 7 in the supplementary file).

\section{Biomass}

The seedlings in the Belgian common garden had significantly lower biomass compared to the seedlings in the Danish common garden $(\mathrm{t}=4.82, \mathrm{p}=<0.001$, table $3 \&$ fig 4$)$. We observed significant effects of the provenance on the biomass of the seedlings $\left(\chi^{2}=18.2, p=<0.05\right.$, table $4)$. We observed a marginal interaction between provenance and common gardens $\left(\chi^{2}=8.5, \mathrm{p}=\right.$ 0.07 , table 4). Heavier acorns produced larger seedlings $(\mathrm{t}=8.1, \mathrm{p}=<0.001$, table 3$)$. 


\section{DISCUSSION}

In the Belgian common garden, the bud burst time of all provenances was nearly four weeks earlier than the Danish common garden. There was an interaction between provenances and common gardens in seedlings' bud burst time. In addition, we observed higher germination rates and biomass of the seedlings in the Danish common garden compared to the Belgian common garden.

\section{Bud burst}

We did not observe any distinct effect of provenances on the bud burst time of the seedlings. Jensen (2010), however, observed significantly different provenance effect on the bud burst of the mature mother trees of the same provenance trial as we studied. We expected the provenance effect on the bud burst time would prevail in mature trees (that means the mother trees) and in the seedlings. In our study, marginally significant effects of the provenance on seedlings' bud burst time could be the result of confounding genetic and environmental effects. We did not observe any provenance effects on the bud burst time of the mother trees (data was not presented), which was likely due to very small sample size (3 to 4 mother trees). We observed some of the mother trees of different provenances to display significant effects on the bud burst time of the seedlings (appendix 5 and appendix 8 in the supplementary file). The influence of mother trees indicate the genetic control on the bud burst time, which probably marginalized the provenances effect in bud burst time of the seedlings. Further, increased genetic diversity can increase the variability in bud burst time among the seedlings within the provenances, which can be expected in an oak stand due to the extensive gene flow and cross-pollination (Elshibli et al. 2015). The mating in European beech, another wind pollinated Fagaceae species, was reported to be restricted to nearby trees (Ouayjan \& Hampe 2018). In oak, Gerber et al. (2014) reported a high level of gene flow with variation among individuals and stands. In our study, there was a high possibility that there was high genetic diversity among the seedlings due to cross-pollination and the effect of the provenance on bud burst of the seedlings was probably influenced by this genetic effect. Using Arabidopsis thaliana and elevated temperature exposure in three generations, Groot et al. (2017) showed that the parental effect changed the flowering time of the offspring and the effect was genotype specific. In another study, Groot et al. (2016) reported that the expression of maternal effects can depend on the offspring environment. In our study, we observed an interaction between provenances and common gardens in bud burst of the seedlings. It is possible that in our study, in addition to seedlings' genetic variability, the offspring environment influenced the bud burst time of the seedlings.

The bud burst time was nearly four weeks earlier in Belgian common garden than Danish common garden, which was circa $2{ }^{\circ} \mathrm{C}$ warmer. Unsurprisingly, advanced bud burst time with warmer conditions in our study was in line with many other studies ((Menzel \& Fabian 1999; Menzel et al. 2006; Richardson et al. 2018). Advancing bud burst time in a warmer environment would provide an advantage to the offspring generation by starting the growing season earlier. Although, it may increase the chance of early frost damage, which ultimately will reduce seedlings growth and thus reduce overall fitness (Richardson et al. 2018). It might be more interesting to know how the seedlings would respond to warming if the mother trees would be exposed to an elevated temperature. This needs further investigation. Earlier bud burst in the Belgian common garden was expected, as the temperature sum requirement would have been fulfilled earlier (Wuehlisch et al. 1995). Besides, photoperiod likely influenced the bud burst time in the Belgian common garden as well since the seedlings in the Belgian common garden received 36 to 14.4 minutes day length longer between 1 February and 1 March compared to those in the Danish common garden (Schreiber et al. 2013; Schueler \& Liesebach 2014). Since 
the temperature requirement for bud burst in $Q$. robur is influenced by precipitation (Fu et al. 2015), it is possible that the higher precipitation in the Belgian common garden compared to the Danish common garden (180 mm difference) also influenced the earlier bud burst of the seedlings in Belgian common garden.

The common environment to which mother trees were exposed for 50 years may have influenced the bud burst time of the seedlings and probably marginalized the provenance effect on the bud burst time of the seedlings. The maternal environmental effect on the performance of the seedlings is also known as transgenerational plasticity effect. Since the design of our study does not allow to test transgenerational plasticity (we did not have contrasting maternal environments), we cannot confirm whether transgenerational plasticity really played an important role in reducing the provenance effect (Latzel 2015). Moreover, at least two generations are generally needed in a common environment before treatments to test transgenerational plasticity can be started (Latzel 2015), which is not very practical for tree species with long generation times. In poplar, it is found that the different environmental conditions to which a similar clone was exposed for centuries can change the bud phenology in the clonal offspring (Vanden Broeck et al. 2018). By exposing single to multi- generations to a stress environment and by evaluating different traits of offspring generation in natural, control and stress conditions, Groot et al. (2016) reported that exposure of multiple generations reduces the parental effect compared to single generation exposure. However, the result of our study certainly opens further research opportunities to detect the influence of transgenerational plasticity while studying local adaptation and tree responses to climate change.

Acorn mass displayed a significant positive influence on the bud burst time by advancing the bud burst time. The effect of seed trait may only be relevant during early development of seedlings and will disappear as the seedlings grow older (Zhang et al. 2017).

\section{Germination and acorn mass}

The observed lower germination in the Belgian common garden compared to Danish one suggests that the environment in common gardens mostly influenced germination. This result supports our expectation regarding the change in germination success with warming. Reduced germination with increasing temperature is known in Quercus species (Rao 1988). Unlike our results, elevated temperature may be advantageous for some species through increasing reproductive success (Milbau et al. 2009), and the responses to an elevated temperature may be different across the species distribution range (De Frenne et al. 2011). The threshold temperature for germination can differ among species and provenances (Baskin \& Baskin 2001; Durr et al. 2015) although we did not find any provenance effect on seed germination. Another critical factor that controls germination of oak acorns is their moisture content. Acorn germination is reduced by decreasing the moisture content below 30 to 50 percent (Olson \& Boyce 1971; Ozbingol 2005). Besides, the moisture conditions of its environment are known to influence the retention of moisture content within the acorn and germination percentage (Korstian 1927). Higher precipitation in the Belgian common garden than the Danish common garden suggests that the moisture content was not the limiting factor for the germination or emergence of seedlings in the Belgian common garden (Olson \& Boyce 1971). Higher soil moisture may have increased the chance of mold formation or other fungal diseases in the acorns of the Belgian common garden. In addition, the common gardens were exposed to two different light conditions. The Danish common garden was open and received more light compared to the Belgian one, which was standing at the edge of a forest. Higher irradiance in 
Danish common garden probably led to warmer soil condition and this warm microclimate probably increased the germination of the acorns. We here quantified acorn germination based on the emergence of the seedlings. We did not re-check the acorns which did not emerge to seedlings to confirm whether the acorns did not germinate at all or the acorns had germinated but were damaged or died of diseases. Having two different site conditions, we are not able to eliminate that other reasons than the warmer climate in the Belgian common garden were also responsible for the lower germination percentage than the Danish one. Nevertheless, our results indicate that environmental conditions of the acorns, that means the microclimate may influence the effects of warming in acorn germination.

There was no difference in acorn mass among the provenances suggesting that acorn mass was probably influenced by the climatic condition of the provenance trial (Borgman et al. 2014). In general, acorn mass in oak is mostly influenced by the local climate (Caignard et al. 2017) and can thus vary across years due to temperature variation (Caignard et al. 2017) and between individuals due to genetic differences (Nikolic \& Orlovic 2002).

\section{Biomass}

Biomass of the seedlings differed across the provenances, which could be the result of genetic variability in different provenances. Reduced biomass in Belgian common garden compared to the seedlings in Danish common garden, indeed, indicate the negative effect of warming on the early growth of the seedlings, which is probably linked with confounding effects such as higher fungal infestation with warming as we observed in the Belgian common garden (Quarles 2007). This result contrasts the general expectation of increased growth with warming (Richardson et al. 2018). Our results indicate that the warming effect on tree growth might be correlated to the temperature gradient along the species distribution range (Reich \& Oleksyn 2008). We observed a marginal interaction between common gardens and provenances. Given the growth responses to temperature can vary with genetic differences (Housset et al. 2018), we suggest that the growth response of the seedlings in two common gardens was likely related to the genetic effect in different provenances. Although, very low variability among the provenances at Belgian common garden in biomass production indicates that growing environmental conditions (e.g., temperature, light) influenced more in biomass production than genetic differences. Environmental factors, such as light availability, can influence the growth of oak seedlings as well (Leuschner \& Meier 2018). The different light condition in two common gardens was likely to influence the growth of the seedlings. The evidence from literature showed that exposure to the sun increases the photosynthesis and carbohydrate concentration of oak seedlings (Baber et al. 2014), which can influence the growth and thus overall fitness of the seedlings. Seedlings in the Belgian common garden received more shade as the common garden was located at the edge of a forest and seedlings in the Danish common garden received almost no shade, as the common garden was located in the open area. Therefore, there was a possible overestimation in our results. Additionally, we observed high fungal infestation (powdery mildew) in the Belgian common garden (no data available) likely due to the existence of oak stand at the vicinity, which could reduce the growth of the seedlings (Bert et al. 2016). Nevertheless, global warming, in general, might be beneficial to some species but not for all species as warming and drought may increase other growth limiting factors such as pest and diseases (Quarles 2007; Reich \& Oleksyn 2008; Dale \& Frank 2017; Perez-Ruiz et al. 2018; Richardson et al. 2018).

In addition, we observed a strong positive correlation between acorn mass and seedling biomass, which can be an indication of maternal influence on seedlings trait (Roach \& Wulff 1987). Due to higher maternal seed provisioning for seedling establishment in heavier acorns, these are usually selected for afforestation purposes via seedling (Bruno et al. 2006; González- 
Rodríguez et al. 2011). Maternal seed provisioning refers the allocation of carbohydrates, lipids, proteins and mineral nutrients by the mother plant into the developing seed, where these reserves of nutrients are mobilized to the embryo germinating seedlings to produce the shoot and root systems (Herman \& Sultan 2011). The strong correlation between inter-annual seed mass and seedling traits in two pine species provides further evidence of parental influence in seedlings performance (Borgman et al. 2014).

\section{Conclusions}

In sum, our results indicate that the effects of warming temperatures in oak depend on the provenance. The effect of provenances in seedlings' bud burst time depends on the temperature condition of the offspring. The results of this study have implications for understanding adaptation to climate change and call for further studies to unravel the role of transgenerational effects on tree adaptation to climate change.

\section{ACKNOWLEDGEMENT}

We acknowledge the Belgian Science Policy Office (BELSPO) for supporting this study under the project FORBIO Climate- Adaptation potential of biodiverse forests in the face of climate change via the BRAIN-be programme. Kris Verheyen was supported by the European Research Council through the PASTFORWARD project (ERC Consolidator Grant 614839) and Pieter De Frenne through the FORMICA project (ERC Starting Grant 757833). We thank Fanny, Filip Ceunen, Haben Blondeel, Inger Kappel Schmidt, Kris Ceunen, Michael Perring and Stefaan Moreels for the assistance in the common gardens and data collection. 


\section{REFERENCES}

Aitken, S.N., Yeaman, S., Holliday, J.A., Wang, T. \& Curtis-McLane, S. 2008. Adaptation, migration or extirpation: climate change outcomes for tree populations. Evol Appl 1: 95111.

Baber, O., Slot, M., Celis, G. \& Kitajima, K. 2014. Diel patterns of leaf carbohydrate concentrations differ between seedlings and mature trees of two sympatric oak species. Botany 92: 535-540.

Baskin, C.C. \& Baskin, J.M. 2001. Seeds: ecology, biogeography, and evolution of dormacy and germination. Acedemic Press, San Diego, California.

Bates, D., Maechler, M., Bolker, B. \& Walker, S. 2015. Fitting Linear Mixed-Effects Models Using lme4. Journal of Statistical Software 67: 1-48.

Beaman, J.E., White, C.R. \& Seebacher, F. 2016. Evolution of Plasticity: Mechanistic Link between Development and Reversible Acclimation. Trends in Ecology \& Evolution 31: 237-249.

Bert, D., Lasnier, J.B., Capdevielle, X., Dugravot, A. \& Desprez-Loustau, M.L. 2016. Powdery Mildew Decreases the Radial Growth of Oak Trees with Cumulative and Delayed Effects over Years. Plos One 11: e0155344.

Borgman, E.M., Schoettle, A.W. \& Angert, A.L. 2014. Using among-year variation to assess maternal effects in Pinus aristata and Pinus flexilis. Botany 92: 805-814.

Borovics, A. \& Mátyás, C. 2013. Decline of genetic diversity of sessile oak at the retracting (xeric) limits. Annals of Forest Science 70: 835-844.

Bradshaw, A.D. 1965. Evolutionary Significance of Phenotypic Plasticity in Plants. In: Caspari, E.W. \& Thoday, J.M. (eds.) Advances in Genetics, pp. 115-155. Academic Press.

Bruno, N.F., Jim’enez, M.N., Ripoll, M.Á., Fern’andez-Ondo no, E., Gallego, E. \& De Simºn, E. 2006. Direct sowing of holm oak acorns: effects of acorn size and soil treatment. Ann. For. Sci. 63: 961-967.

Caignard, T., Kremer, A., Firmat, C., Nicolas, M., Venner, S. \& Delzon, S. 2017. Increasing spring temperatures favor oak seed production in temperate areas. Sci Rep 7: 8555.

Carvalho, D.E., Ingvarsson, P.K., Joseph, J., Suter, L., Sedivy, C., Macaya-Sanz, D., Cottrell, J., Heinze, B., Schanzer, I. \& Lexer, C. 2010. Admixture facilitates adaptation from standing variation in the European aspen (Populus tremula L.), a widespread forest tree. Molecular Ecology 19: 1638-1650.

Christensen, J.H., Krishna Kumar, K., Aldrian, E., An, S.-I., Cavalcanti, I.F.A., de Castro, M., Dong, W., Goswami, P., Hall, A., Kanyanga, J.K., Kitoh, A., Kossin, J., Lau, N.-C., Renwick, J., Stephenson, D.B., Xie, S.-P. \& Zhou, T. 2013. Climate Phenomena and their Relevance for Future Regional Climate Change. . In: Stocker, T.F., Qin, D., Plattner, G.-K., Tignor, M., Allen, S.K., Boschung, J., Nauels, A., Xia, Y., Bex, V. \& Midgley, P.M. (eds.) Climate Change 2013: The Physical Science Basis. Contribution of Working Group I to the Fifth Assessment Report of the Intergovernmental Panel on Climate Change, pp. 1217-1308. Cambridge University Press, Cambridge, UK \& New York, NY, USA.

Dale, A.G. \& Frank, S.D. 2017. Warming and drought combine to increase pest insect fitness on urban trees. Plos One 12: e0173844.

De Frenne, P., Brunet, J., Shevtsova, A., Kolb, A., Graae, B.J., Chabrerie, O., Cousins, S.A., Decocq, G., De Schrijver, A.N., Diekmann, M., Gruwez, R., Heinken, T., Hermy, M., Nilsson, C., Stanton, S., Tack, W., Willaert, J. \& Verheyen, K. 2011. Temperature effects on forest herbs assessed by warming and transplant experiments along a latitudinal gradient. Global Change Biology 17: 3240-3253. 
Delzon, S., Urli, M., Samalens, J.C., Lamy, J.B., Lischke, H., Sin, F., Zimmermann, N.E. \& Porte, A.J. 2013. Field evidence of colonisation by Holm Oak, at the northern margin of its distribution range, during the Anthropocene period. Plos One 8: e80443.

Dewan, S., De Frenne, P., Vanden Broeck, A., Steenackers, M., Vander Mijnsbrugge, K. \& Verheyen, K. 2018. Transgenerational effects in asexually reproduced offspring of Populus. Plos One 13: e0208591.

Drobyshev, I., Niklasson, M., Eggertsson, O., Linderson, H. \& Sonesson, K. 2008. Influence of annual weather on growth of pedunculate oak in southern Sweden. Annals of Forest Science 65: 512.

Durr, C., Dickie, J.B., Yang, X.Y. \& Pritchard, H.W. 2015. Ranges of critical temperature and water potential values for the germination of species worldwide: Contribution to a seed trait database. Agricultural and Forest Meteorology 200: 222-232.

Elshibli, S., Raisio, J., Varis, S., Vakkari, P. \& Pulkkinen, P. 2015. Genetic variation of pedunculate oak (Quercus roburL.) in the urban woodlands of Helsinki. Scandinavian Journal of Forest Research 31: 140-147.

Fick, S.E. \& Hijmans, R.J. 2017. WorldClim 2: new 1-km spatial resolution climate surfaces for global land areas. International Journal of Climatology 37: 4302-4315.

Fu, Y.H., Piao, S., Vitasse, Y., Zhao, H., De Boeck, H.J., Liu, Q., Yang, H., Weber, U., Hanninen, H. \& Janssens, I.A. 2015. Increased heat requirement for leaf flushing in temperate woody species over 1980-2012: effects of chilling, precipitation and insolation. Glob Chang Biol 21: 2687-2697.

Galloway, L.F. \& Etterson, J.R. 2007. Transgenerational Plasticity Is Adaptive in the Wild. SCIENCE 318: 1134-1136.

Gerber, S., Chadoeuf, J., Gugerli, F., Lascoux, M., Buiteveld, J., Cottrell, J., Dounavi, A., Fineschi, S., Forrest, L.L., Fogelqvist, J., Goicoechea, P.G., Jensen, J.S., Salvini, D., Vendramin, G.G. \& Kremer, A. 2014. High rates of gene flow by pollen and seed in oak populations across Europe. Plos One 9: e85130.

González-Rodríguez, V., Villar, R. \& Navarro-Cerrillo, R.M. 2011. Maternal influences on seed mass effect and initial seedling growth in four Quercus species. Acta Oecologica 37: $1-9$.

Groot, M.P., Kooke, R., Knoben, N., Vergeer, P., Keurentjes, J.J.B., Ouborg, N.J. \& Verhoeven, K.J.F. 2016. Effects of Multi-Generational Stress Exposure and Offspring Environment on the Expression and Persistence of Transgenerational Effects in Arabidopsis thaliana. Plos One 11.

Groot, M.P., Kubisch, A., Ouborg, N.J., Pagel, J., Schmid, K.J., Vergeer, P. \& Lampei, C. 2017. Transgenerational effects of mild heat in Arabidopsis thaliana show strong genotype specificity that is explained by climate at origin. New Phytologist 215: 1221-1234.

Hansen, J., Sato, M., Ruedy, R., Lo, K., Lea, D.W.a. \& Medina-Elizade, M. 2006. Global temperature change. PNAS 103: 14288-14293.

Herman, J.J. \& Sultan, S.E. 2011. Adaptive transgenerational plasticity in plants: case studies, mechanisms, and implications for natural populations. Frontiers in Plant Science 2: 102.

Hoffmann, A.A. \& Sgro, C.M. 2011. Climate change and evolutionary adaptation. Nature 470: 479-485.

Housset, J.M., Nadeau, S., Isabel, N., Depardieu, C., Duchesne, I., Lenz, P. \& Girardin, M.P. 2018. Tree rings provide a new class of phenotypes for genetic associations that foster insights into adaptation of conifers to climate change. New Phytologist 218: 630-645.

IPCC. 2013. Summary for Policymakers. In: Stocker, T.F., Qin, D., Plattner, G.-K., Tignor, M., Allen, S.K., Boschung, J., Nauels, A., Xia, Y., Bex, V. \& Midgley, P.M. (eds.) Climate Change 2013: The Physical Science Basis. Contribution of Working Group I to the Fifth 
Assessment Report of the Intergovernmental Panel on Climate Change., Cambridge, United Kingdom and New York, NY, USA.

Jablonka, E. 2013. Epigenetic inheritance and plasticity: The responsive germline. Prog Biophys Mol Biol 111: 99-107.

Jensen, J.S. 2010. Provenance Variation in Phenotypic Traits in Quercus robur and Quercus petraea in Danish Provenance Trials. Scandinavian Journal of Forest Research 15: 297 308.

Johnson, P.S., Shifley, S.R. \& Rogers, R. 2002. The Ecology and Silviculture of Oaks. CABI Publoshing, New York, USA.

Jones, E.W. 1959. BIOLOGICAL FLORA OF THE BRITISH ISLES: QUERCUS L. Journal of Ecology 47: 169-222.

Korstian, C.F. 1927. Factors Controlling Germination and Early Survival in Oaks. Yale School of Forestry Bulletin 19.

Kozharinov, A.V. \& Borisov, P.V. 2014. Distribution of oak forests in Eastern Europe over the last 13000 years. Contemporary Problems of Ecology 6: 755-760.

Kremer, A. 2016. Microevolution of European temperate oaks in response to environmental changes. Comptes Rendus Biologies 339: 263-267.

Kuijper, B. \& Hoyle, R.B. 2015. When to rely on maternal effects and when on phenotypic plasticity? Evolution 69: 950-968.

Kullman, L. 2002. Rapid recent range-margin rise of tree and shrub species in the Swedish Scandes. Journal of Ecology 90: 68-77.

Lacey, E.P., Smith, S. \& Case, A.L. 1997. Parental effects on seed mass: seed coat but not embryo/endosperm effects. American Journal of Botany 84: 1617-1620.

Lampei, C., Metz, J. \& Tielborger, K. 2017. Clinal population divergence in an adaptive parental environmental effect that adjusts seed banking. New Phytologist 214: 12301244.

Latzel, V. 2015. Pitfalls in ecological research - transgenerational effects. Folia Geobotanica 50: 75-85.

Latzel, V., Janeček, Š., Doležal, J., Klimešová, J. \& Bossdorf, O. 2014. Adaptive transgenerational plasticity in the perennialPlantago lanceolata. Oikos 123: 41-46.

Leuschner, C. \& Meier, I.C. 2018. The ecology of Central European tree species: Trait spectra, functional trade-offs, and ecological classification of adult trees. Perspectives in Plant Ecology, Evolution and Systematics 33: 89-103.

Loarie, S.R., Duffy, P.B., Hamilton, H., Asner, G.P., Field, C.B. \& Ackerly, D.D. 2009. The velocity of climate change. Nature 462: 1052-1055.

Menzel, A. \& Fabian, P. 1999. Growing season extended in Europe. Nature 397: 659.

Menzel, A., Sparks, T.H., Estrella, N., Koch, E., Aasa, A., Ahas, R., Alm-KÜBler, K., Bissolli, P., BraslavskÁ, O.G., Briede, A., Chmielewski, F.M., Crepinsek, Z., Curnel, Y., Dahl, Å., Defila, C., Donnelly, A., Filella, Y., Jatczak, K., MÅGe, F., Mestre, A., Nordli, Ø., PeÑUelas, J., Pirinen, P., RemiŠOvÁ, V., Scheifinger, H., Striz, M., Susnik, A., Van Vliet, A.J.H., Wielgolaski, F.-E., Zach, S. \& Zust, A.N.A. 2006. European phenological response to climate change matches the warming pattern. Global Change Biology 12: 1969-1976.

Milbau, A., Graae, B.J., Shevtsova, A. \& Nijs, I. 2009. Effects of a warmer climate on seed germination in the subarctic. Annals of Botany 104: 287-296.

Munzbergova, Z. \& Hadincova, V. 2017. Transgenerational plasticity as an important mechanism affecting response of clonal species to changing climate. Ecol Evol 7: 52365247. 
Nicotra, A.B., Atkin, O.K., Bonser, S.P., Davidson, A.M., Finnegan, E.J., Mathesius, U., Poot, P., Purugganan, M.D., Richards, C.L., Valladares, F. \& van Kleunen, M. 2010. Plant phenotypic plasticity in a changing climate. Trends in Plant Science 15: 684-692.

Nikolic, N. \& Orlovic, S. 2002. Genotypic variability of morphological characteristics of English oak (Quercus robur L) acorn. Zbornik Matice srpske za prirodne nauke: 53-58.

Olson, D.F.J. \& Boyce, S.G. 1971. Factors affecting acorn production and germination and early growth of seedlings and seedling sprouts the Oak Symposium, pp. 44-48. USDA Forest Service, Northeast Forest Experimental Station, Radnor, PA: West Virginia University, Morgantown, WV.

Olson, M.S., Levsen, N., Soolanayakanahally, R.Y., Guy, R.D., Schroeder, W.R., Keller, S.R. \& Tiffin, P. 2013. The adaptive potential of Populus balsamifera L. to phenology requirements in a warmer global climate. Molecular Ecology 22: 1214-1230.

Ouayjan, A. \& Hampe, A. 2018. Extensive sib-mating in a refugial population of beech ( Fagus sylvatica ) growing along a lowland river. Forest Ecology and Management 407: 6674.

Ozbingol, N. 2005. Increasing acorn moisture content followed by freezing-storage enhances germination in pedunculate oak. Forestry 78: 73-81.

Perez-Ruiz, C.L., Badano, E.I., Rodas-Ortiz, J.P., Delgado-Sanchez, P., Flores, J., Douterlungne, D. \& Flores-Cano, J.A. 2018. Climate change in forest ecosystems: A field experiment addressing the effects of raising temperature and reduced rainfall on early life cycle stages of oaks. Acta Oecologica-International Journal of Ecology 92: $35-43$.

Quarles, W. 2007. Global warming means more pests. The IPM Practitioner 29: 1-8.

R Core Team. 2017. R: A language and environment for statistical computing. R Foundation for Statistical Computing: Vienna, Austria.

Raj, S., Brautigam, K., Hamanishi, E.T., Wilkins, O., Thomas, B.R., Schroeder, W., Mansfield, S.D., Plant, A.L. \& Campbell, M.M. 2011. Clone history shapes Populus drought responses. Proceedings of the National Academy of Sciences of the United States of America 108: 12521-12526.

Rao, P.B. 1988. Effects of Environmental Factors on Germination and Seedling Growth in Quercus floribunda and Cupressus torulosa. Tree Species of Central Himalaya. Annals of Bolany 61: 531-540.

Reich, P.B. \& Oleksyn, J. 2008. Climate warming will reduce growth and survival of Scots pine except in the far north. Ecology Letters 11: 588-597.

Richardson, A.D., Hufkens, K., Milliman, T., Aubrecht, D.M., Furze, M.E., Seyednasrollah, B., Krassovski, M.B., Latimer, J.M., Nettles, W.R., Heiderman, R.R., Warren, J.M. \& Hanson, P.J. 2018. Ecosystem warming extends vegetation activity but heightens vulnerability to cold temperatures. Nature 560: 368-371.

Roach, D.A. \& Wulff, R.D. 1987. MATERNAL EFFECTS IN PLANTS. Anti. Rev. Ecol. Svst. 18: 209-235.

Rozas, V. 2005. Dendrochronology of pedunculate oak (Quercus robur L.) in an old-growth pollarded woodland in northern Spain: tree-ring growth responses to climate. Annals of Forest Science 62: 209-218.

Saenz-Romero, C., Lamy, J.B., Ducousso, A., Musch, B., Ehrenmann, F., Delzon, S., Cavers, S., Chalupka, W., Dagdas, S., Hansen, J.K., Lee, S.J., Liesebach, M., Rau, H.M., Psomas, A., Schneck, V., Steiner, W., Zimmermann, N.E. \& Kremer, A. 2017. Adaptive and plastic responses of Quercus petraea populations to climate across Europe. Glob Chang Biol 23: 2831-2847. 
Schreiber, S.G., Ding, C., Hamann, A., Hacke, U.G., Thomas, B.R., Brouard, J.S. \& Saura, S. 2013. Frost hardiness vs. growth performance in trembling aspen: an experimental test of assisted migration. Journal of Applied Ecology 50: 939-949.

Schueler, S. \& Liesebach, M. 2014. Latitudinal population transfer reduces temperature sum requirements for bud burst of European beech. Plant Ecology.

Vanden Broeck, A., Cox, K., Brys, R., Castiglione, S., Cicatelli, A., Guarino, F., Heinze, B., Steenackers, M. \& Vander Mijnsbrugge, K. 2018. Variability in DNA Methylation and Generational Plasticity in the Lombardy Poplar, a Single Genotype Worldwide Distributed Since the Eighteenth Century. Plos One 9.

Wesołowski, T. \& Rowiński, P. 2006. Timing of bud burst and tree-leaf development in a multispecies temperate forest. Forest Ecology and Management 237: 387-393.

Wesołowski, T., Rowiński, P. \& Maziarz, M. 2014. Interannual variation in tree seed production in a primeval temperate forest: does masting prevail? European Journal of Forest Research 134: 99-112.

Whitlock, M.C. 2015. Modern Approaches to Local Adaptation. The American Naturalist 186: S1-S4.

Wilkinson, M., Eaton, E.L. \& Morison, J.I.L. 2017. Variation in the date of budburst in Quercus robur and Q-petraea across a range of provenances grown in Southern England. European Journal of Forest Research 136: 1-12.

Wuehlisch, G.V., Krusche, D. \& Muhs, H.J. 1995. Variation in Temperature Sum Requirement for Flushing of Beech Provenances. Silvae Genetica 44: 343-346.

Zhang, H., Yang, X., Yu, M., Han, Y. \& Wu, T. 2017. Variations in seed size and seed mass related to tree growth over 5 years for 23 provenances of Quercus acutissima from across China. Journal of Forestry Research 28: 917-923. 


\section{Figures and Tables}

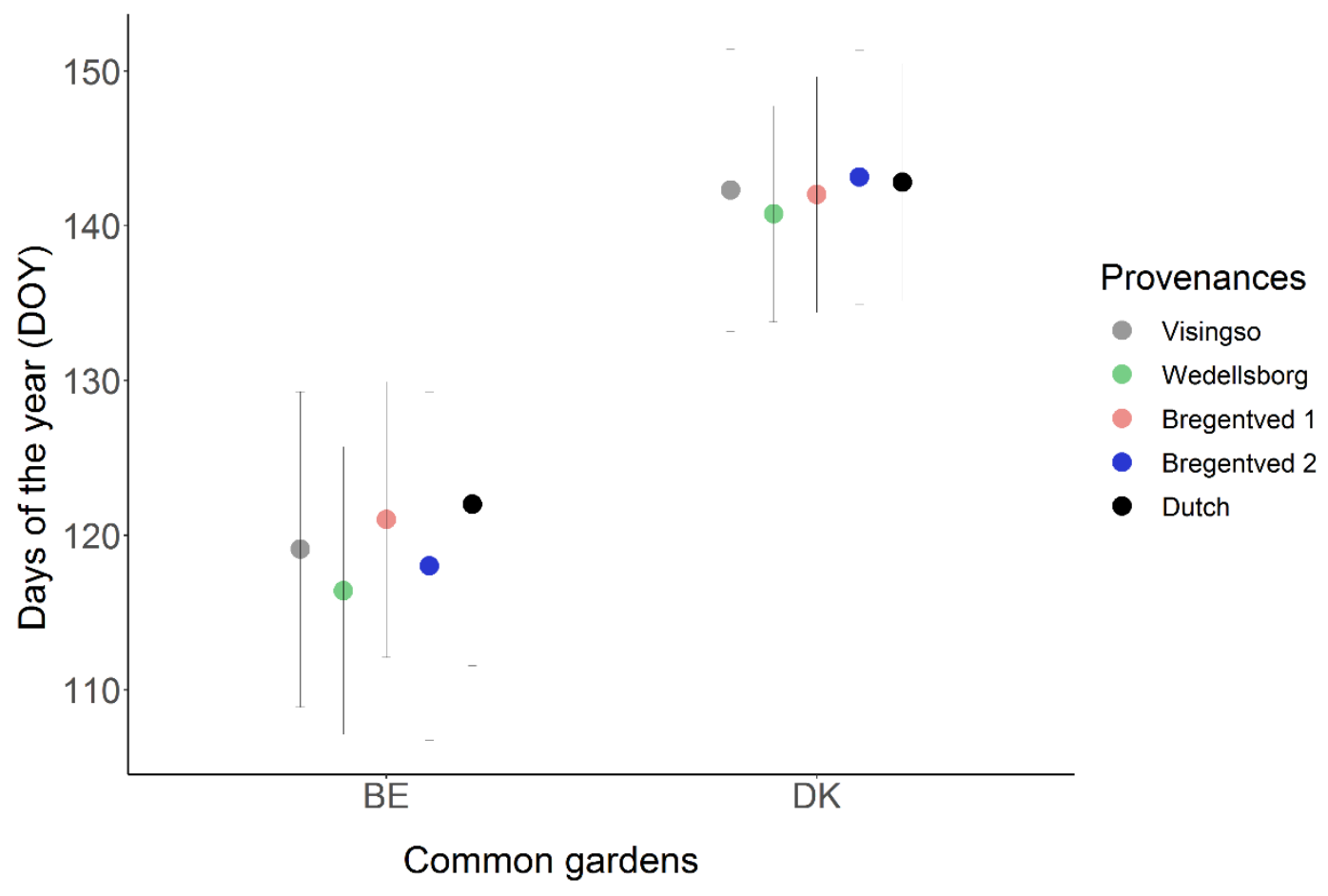

Figure 1 -- Bud burst dates (between day of the year, DOY, 100 to 160) of the 5 provenances in the Belgian (BE) and Danish (DK) common gardens. The seedlings in the Belgian common garden displayed earlier bud burst than Danish common garden. The error bars denote the standard deviation. 

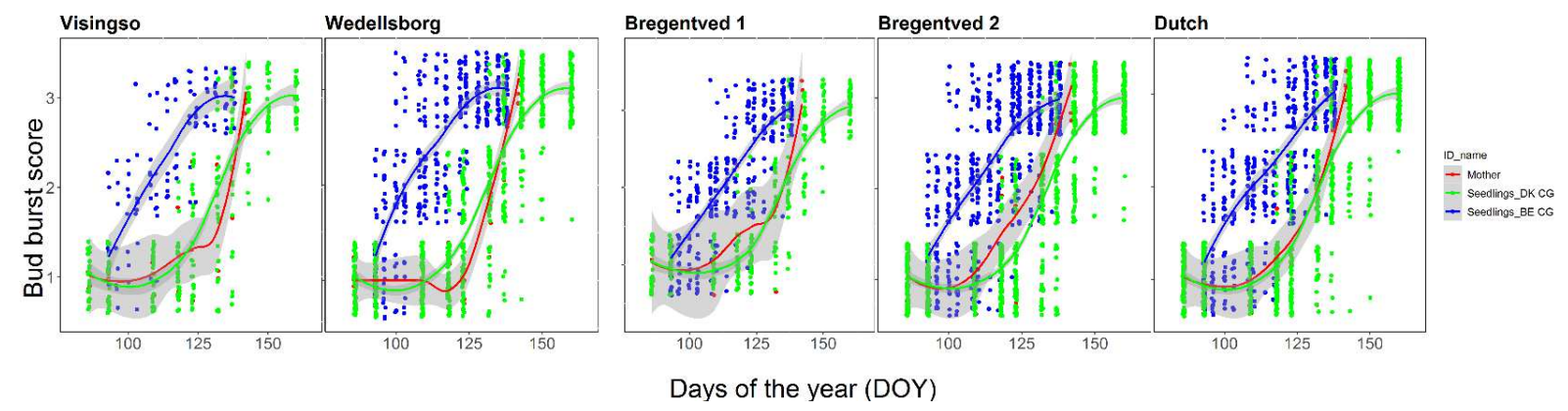

Figure 2 -- The bud burst score in the mother trees and the seedlings in two common gardens in five different provenances. "Seedlings_DK CG" and "Seedlings_BE CG" refer to seedlings in the Danish common garden and seedlings in the Belgian common garden, respectively. The curves and respective confidence interval (95\%) were fitted using the method 'loess' in $\mathrm{R}$. We jittered the data points for clarity along the Y-axis. 


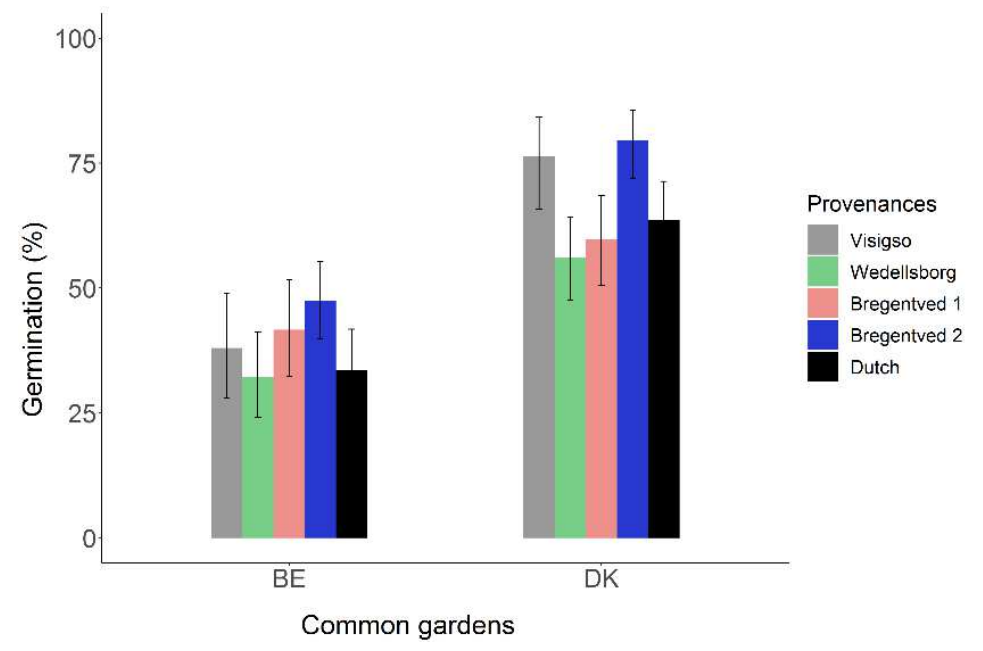

Figure 3 -- Seed germination (\%) of five different provenances in the Belgian (BE) and the Danish (DK) common gardens. Germination percentage was quantified based on the total number of seedlings emerged from sowed acorns. Error bars denote the confidence intervals $(95 \%)$. 


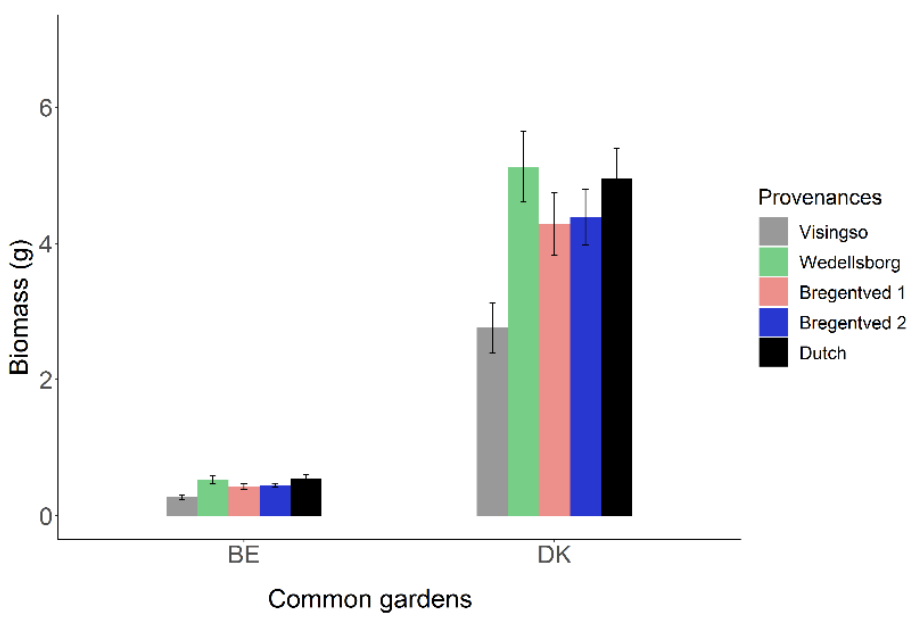

Figure 4 -- Biomass of the seedlings for the five provenances in the Belgian (BE) and Danish (DK) common gardens. The biomass of the seedlings in all provenances in the Belgian common garden was much lower compared to the seedlings in the Danish common garden. Error bars denote the standard error. 
Table 1- Background information on the provenance trial and the common gardens. Climatic data (averaged across 1970-2000) were extracted from the WorldClim version 2 dataset (Fick \& Hijmans 2017).

\begin{tabular}{lllllll}
\hline Site & Location/country & $\begin{array}{l}\text { Latitude } \\
\left({ }^{\circ}\right)\end{array}$ & $\begin{array}{l}\text { Longitude } \\
\left({ }^{\circ}\right)\end{array}$ & $\begin{array}{l}\text { Elevation } \\
(\mathrm{m} \text { a. s. 1.) }\end{array}$ & $\begin{array}{l}\text { Mean } \\
\text { annual } \\
\text { temperature } \\
\left({ }^{\circ} \mathrm{C}\right)\end{array}$ & $\begin{array}{l}\text { Mean annual } \\
\text { precipitation } \\
(\mathrm{mm})\end{array}$ \\
\hline $\begin{array}{l}\text { Provenance } \\
\text { trial }\end{array}$ & Nyskov/ Denmark & 55.33 & 12.07 & 19 & 8.4 & 597 \\
$\begin{array}{l}\text { Common } \\
\text { garden 1 }\end{array}$ & Copenhagen/Denmark & 55.68 & 12.54 & 9 & 8.6 & 612 \\
$\begin{array}{l}\text { Common } \\
\text { garden 2 }\end{array}$ & Gontrode/Belgium & 50.98 & 3.81 & 21 & 10.2 & 795 \\
\hline
\end{tabular}


Table 2 - Description of the scoring system of bud phenology. Three stages of bud burst in the seedlings of oak were quantified based on visual observations adapted after Wesołowski and Rowiński (2006).

\begin{tabular}{ll}
\hline Score & Description \\
\hline 1 & $\begin{array}{l}\text { Undeveloped, all stages from } \\
\text { sleeping bud, to a bud with broken } \\
\text { scales, tips of leaves visible but } \\
\text { still forming a single bud tip }\end{array}$ \\
\hline 2 & $\begin{array}{l}\text { Broken-from small leaves with } \\
\text { bases still hidden in bud scales but } \\
\text { tips detached from the bud axis, till } \\
\text { small leaves with folded } \\
\text { (incompletely unfolded) leaf } \\
\text { blades }\end{array}$ \\
\hline 3 & $\begin{array}{l}\text { Developed, small completely } \\
\text { unfolded leaf blade }\end{array}$ \\
\hline
\end{tabular}


Table 3 -- The estimated parameters from (Generalised) Linear mixed effects models. The bud burst time, germination, and biomass of the seedlings was analysed as a function of common garden, provenance and acorn mass. DK means Danish common garden (as reference treatment compared to the Belgian common garden).

\begin{tabular}{|c|c|c|c|c|c|}
\hline \multicolumn{6}{|l|}{ Fixed effects } \\
\hline Response & Effect & Estimate & $\begin{array}{r}\text { Std. } \\
\text { Error }\end{array}$ & $\mathrm{z}$ value & $\mathrm{p}$ value \\
\hline \multirow[t]{12}{*}{ Bud burst } & (Intercept) & 3.63 & 0.04 & 85.97 & $<0.001$ \\
\hline & Common garden DK & 0.49 & 0.04 & 13.60 & $<0.001$ \\
\hline & Bregentved 2 & -0.10 & 0.05 & -2.13 & $<0.05$ \\
\hline & Dutch & 0.02 & 0.05 & 0.43 & 0.67 \\
\hline & Visingso & -0.08 & 0.06 & -1.39 & 0.17 \\
\hline & Wedellsborg & -0.11 & 0.06 & -2.03 & $<0.05$ \\
\hline & Acorn mass & -0.02 & 0.01 & -3.48 & $<0.001$ \\
\hline & Common garden DK : Bregentved 2 & 0.10 & 0.04 & 2.32 & $<0.05$ \\
\hline & Common garden DK : Dutch & -0.02 & 0.05 & -0.42 & 0.68 \\
\hline & Common garden DK: Visingso & 0.06 & 0.06 & 1.0 & 0.32 \\
\hline & Common garden DK: Wedellsborg & 0.10 & 0.05 & 1.84 & 0.07 \\
\hline & & Estimate & $\begin{array}{l}\text { Std. } \\
\text { Error }\end{array}$ & $\mathrm{z}$ value & $\mathrm{p}$ value \\
\hline \multirow[t]{12}{*}{ Germination } & (Intercept) & -0.28 & 0.47 & -0.59 & 0.56 \\
\hline & Common garden DK & 1.10 & 0.48 & 2.31 & $<0.05$ \\
\hline & Bregentved 2 & 0.21 & 0.43 & 0.49 & 0.63 \\
\hline & Dutch & -0.63 & 0.44 & -1.43 & 0.15 \\
\hline & Visingso & -0.23 & 0.49 & -0.46 & 0.64 \\
\hline & Wedellsborg & -0.44 & 0.45 & -0.98 & 0.33 \\
\hline & Acorn mass & -0.02 & 0.07 & -0.30 & 0.76 \\
\hline & Common garden DK : Bregentved 2 & 0.54 & 0.47 & 1.17 & 0.24 \\
\hline & Common garden DK : Dutch & 0.35 & 0.45 & 0.78 & 0.44 \\
\hline & Common garden DK: Visingso & 0.58 & 0.54 & 1.07 & 0.29 \\
\hline & Common garden DK: Wedellsborg & -0.09 & 0.46 & -0.2 & 0.84 \\
\hline & & Estimate & $\begin{array}{l}\text { Std. } \\
\text { Error }\end{array}$ & $\mathrm{t}$ value & $\mathrm{p}$ value \\
\hline \multirow[t]{11}{*}{ Biomass } & (Intercept) & -2.55 & 0.71 & -3.57 & $<0.001$ \\
\hline & Common garden DK & 3.11 & 0.65 & 4.82 & $<0.001$ \\
\hline & Bregentved 2 & 0.21 & 0.75 & 0.29 & 0.78 \\
\hline & Dutch & 0.16 & 0.81 & 0.20 & 0.84 \\
\hline & Visingso & 0.15 & 0.91 & 0.16 & 0.87 \\
\hline & Wedellsborg & -1.41 & 0.87 & -1.63 & 0.11 \\
\hline & Acorn mass & 0.97 & 0.12 & 8.1 & $<0.001$ \\
\hline & Common garden DK : Bregentved 2 & 0.74 & 0.74 & 1.00 & 0.32 \\
\hline & Common garden DK : Dutch & 1.18 & 0.82 & 1.43 & 0.15 \\
\hline & Common garden DK: Visingso & -0.78 & 0.92 & -0.84 & 0.40 \\
\hline & Common garden DK: Wedellsborg & 1.61 & 0.87 & 1.85 & 0.07 \\
\hline
\end{tabular}


Table 4 - The effects of the common garden, provenance, acorn mass and the interaction between common gardens and provenances on germination, bud burst time and shoot biomass of oak seedlings. Results from likelihood ratio tests.

\begin{tabular}{lllll}
\hline Response & Effect & $\chi^{2}$-value & df & p value \\
\hline Germination & Common garden & 14.9 & 5 & $<0.05^{*}$ \\
& Provenance & 10.9 & 8 & 0.21 \\
& Common garden x Provenance & 3.3 & 4 & 0.51 \\
& Acorn mass & 0.1 & 1 & 0.76 \\
\hline Bud burst & Common garden & 132.3 & 5 & $<0.001^{* * *}$ \\
& Provenance & 13.8 & 8 & $0.09 \cdot$ \\
& Common garden x Provenance & 11.4 & 4 & $<0.05^{*}$ \\
& Acorn mass & 11.9 & 1 & $<0.01^{* *}$ \\
& Common garden & 61.0 & 5 & $<0.001^{* * *}$ \\
& Provenance & 18.2 & 8 & $<0.05^{*}$ \\
& Common garden x Provenance & 8.5 & 4 & $0.07 \cdot$ \\
\hline
\end{tabular}

Significance denoted by “.” $\mathrm{p}<0.100,{ }^{*} \mathrm{p}<0.05, * * \mathrm{p}<0.01, * * * \mathrm{p}<0.001$ 


\section{Appendices}

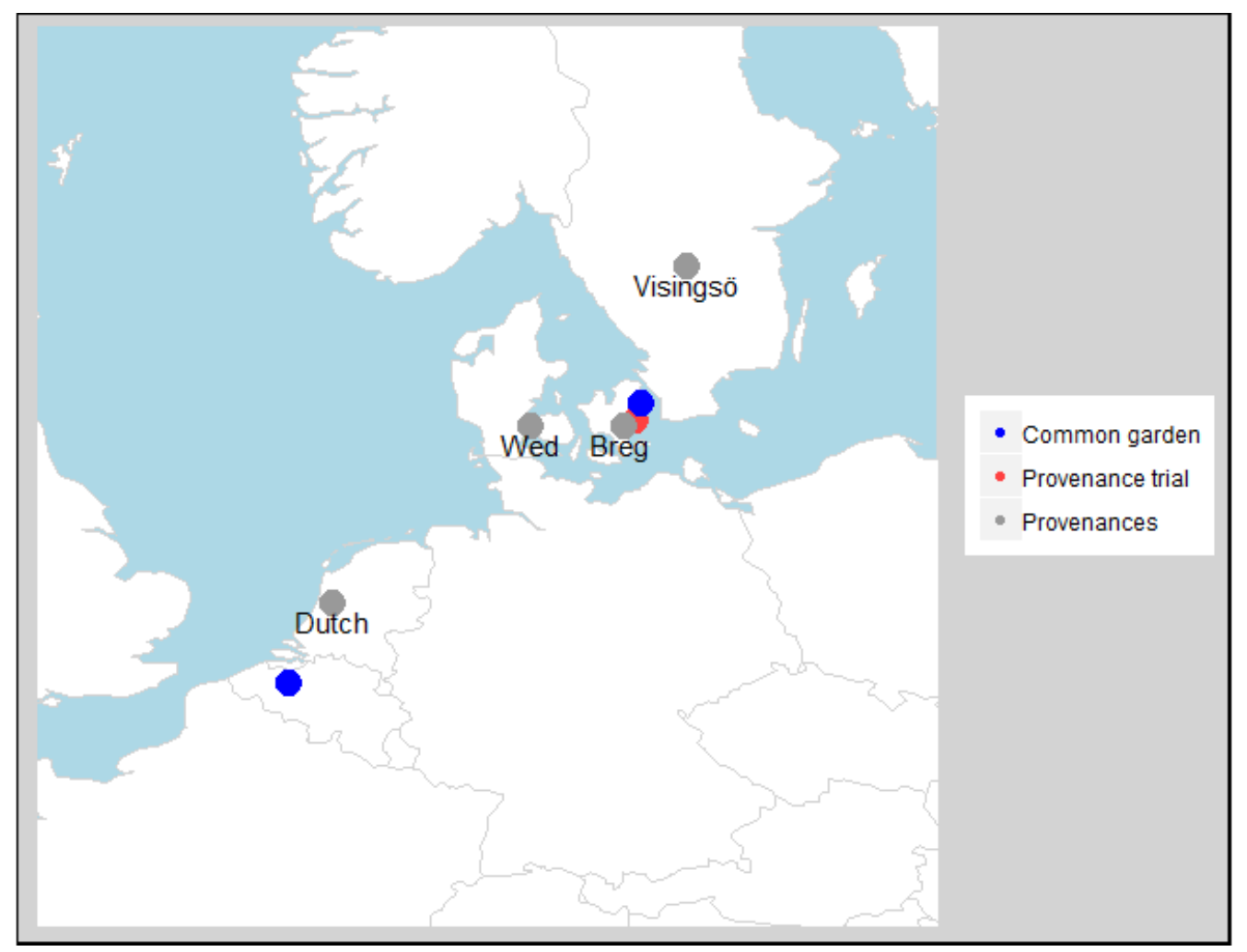

Appendix 1-- The location of the provenance trial, different provenances and common gardens.

"Wed" means Wedellsborg and "Breg" means Bregentved provenance in Denmark. The northern blue dot represents the common garden in Denmark and the southern blue dot represents the common garden in Belgium. The exact location of the "Dutch" provenance was unkown. 
Appendix 2 -- Total number of acorns and seedlings from each mother tree and provenance in Belgian and Danish common garden. 'CG' refers to common garden.

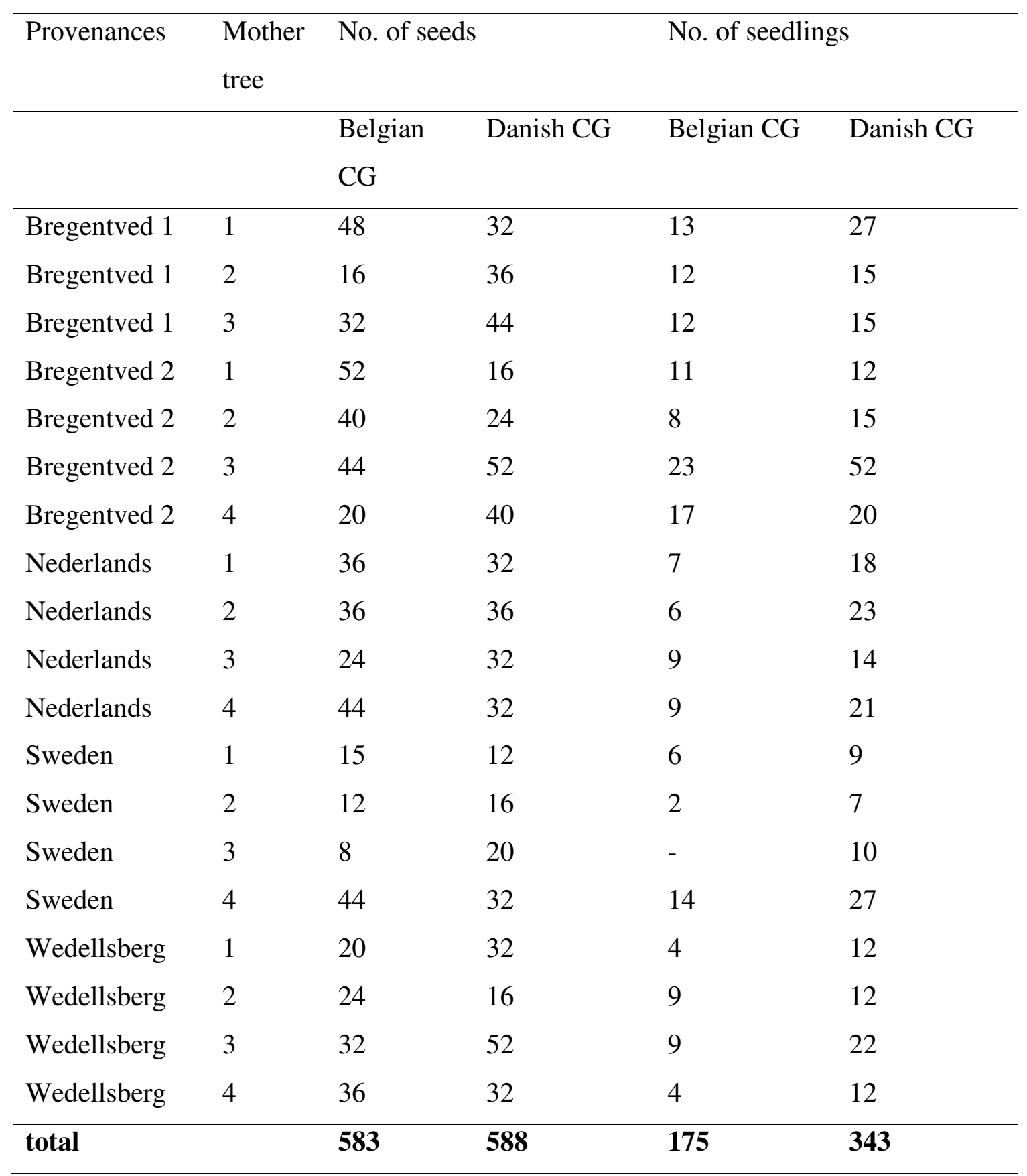


Appendix 3 --The overview of the number of seedlings, mother trees and Trays in two common gardens in Belgium and Denmark.

\begin{tabular}{llllll}
\hline $\begin{array}{l}\text { Common } \\
\text { garden }\end{array}$ & $\begin{array}{l}\text { No. } \\
\text { seedlings }\end{array}$ & $\begin{array}{l}\text { No. of } \\
\text { mother trees }\end{array}$ & & $\begin{array}{l}\text { No. of Trays } \\
\text { mother trees } \\
\text { / Tray }\end{array}$ & $\begin{array}{l}\text { Mean no. of } \\
\text { seedlings/Tray }\end{array}$ \\
\hline Belgium & 175 & 18 & 21 & 3 & 8.8 \\
Denmark & 343 & 19 & 20 & 5 & 16.3 \\
\hline
\end{tabular}




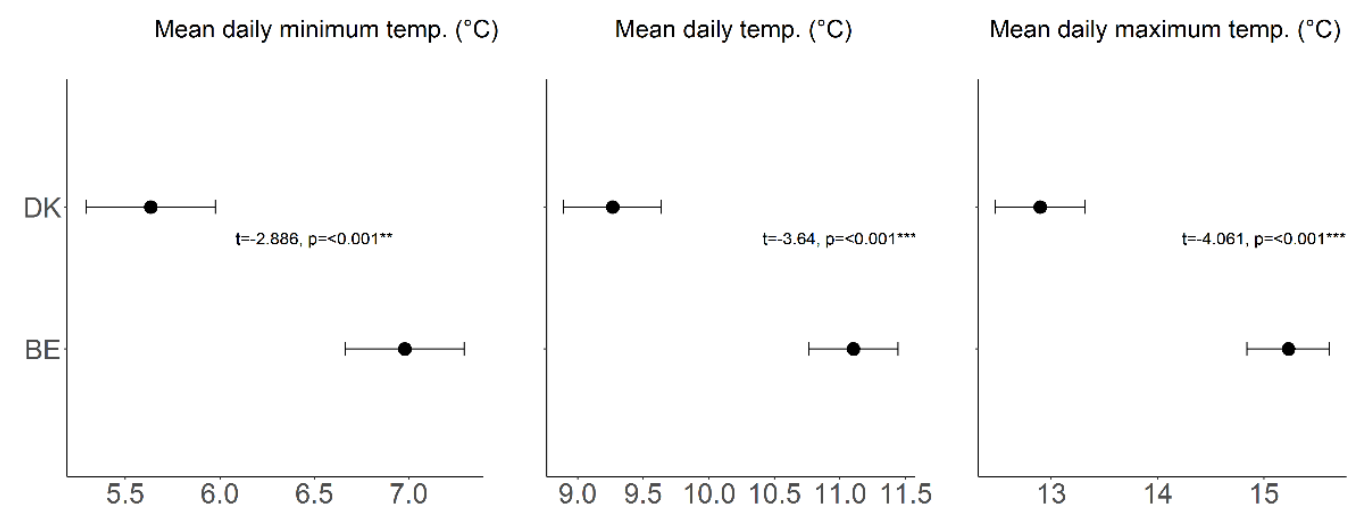

Appendix 4 -- Daily minimum, mean and maximal temperatures in the Danish common garden (DK) and Belgian common garden (BE) in 2016. Values are t values and p values from linear models Error bars indicate standard errors. Significance are denoted by ** $\mathrm{p}<0.01$, *** $\mathrm{p}<0.001$ 
Appendix 5 -- The estimated parameters from (Generalised) Linear mixed effects models. The bud burst time of the seedlings was analysed as a function of common garden, provenance, mother tree (ID) and acorn mass. DK means Danish common garden, b1, b2, d, v and w means Bregentved 1, Bregentved 2, Dutch, Visingso and Wedellsborg provenance respectively, and $\mathrm{m} 1, \mathrm{~m} 2 \mathrm{~m} 3$ means the number of mother trees.

\begin{tabular}{|l|l|l|l|l|}
\hline Bud burst & Estimate & Std. Error & z value & p value \\
\hline (Intercept) & 3.579 & 0.049 & 72.539 & $<0.001$ \\
\hline Common garden DK & 0.491 & 0.036 & 13.772 & $<0.001$ \\
\hline Bregentved 2 & -0.047 & 0.050 & -0.946 & 0.344 \\
\hline Dutch & 0.131 & 0.054 & 2.438 & $<0.05$ \\
\hline Visingso & -0.002 & 0.056 & -0.034 & 0.973 \\
\hline Wedellsborg & -0.037 & 0.065 & -0.577 & 0.564 \\
\hline Acorn mass & -0.023 & 0.008 & -3.084 & $<0.01$ \\
\hline b1m2 & 0.028 & 0.044 & 0.639 & 0.523 \\
\hline b1m3 & 0.112 & 0.040 & 2.823 & $<0.01$ \\
\hline b2m1 & 0.057 & 0.043 & 1.338 & 0.181 \\
\hline b2m2 & -0.105 & 0.044 & -2.404 & $<0.05$ \\
\hline b2m3 & 0.003 & 0.035 & 0.077 & 0.938 \\
\hline dm1 & -0.088 & 0.041 & -2.150 & $<0.05$ \\
\hline dm2 & -0.130 & 0.038 & -3.453 & $<0.001$ \\
\hline dm3 & -0.039 & 0.042 & -0.936 & 0.349 \\
\hline vm1 & -0.091 & 0.049 & -1.876 & 0.061 \\
\hline vm2 & -0.034 & 0.055 & -0.619 & 0.536 \\
\hline vm3 & 0.022 & 0.055 & 0.408 & 0.683 \\
\hline wm1 & -0.058 & 0.060 & -0.967 & 0.334 \\
\hline wm2 & -0.084 & 0.057 & -1.469 & 0.142 \\
\hline wm3 & 0.030 & 0.052 & 0.577 & 0.564 \\
\hline Common garden DK : Bregentved & 0.102 & 0.044 & 2.339 & $<0.05$ \\
\hline 2 & -0.018 & 0.048 & -0.380 & 0.704 \\
\hline Common garden DK : Dutch & 0.044 & 0.056 & 0.789 & 0.430 \\
\hline Common garden DK : Visingso & 0.053 & 1.711 & 0.087 \\
\hline Common & & & & \\
\hline
\end{tabular}




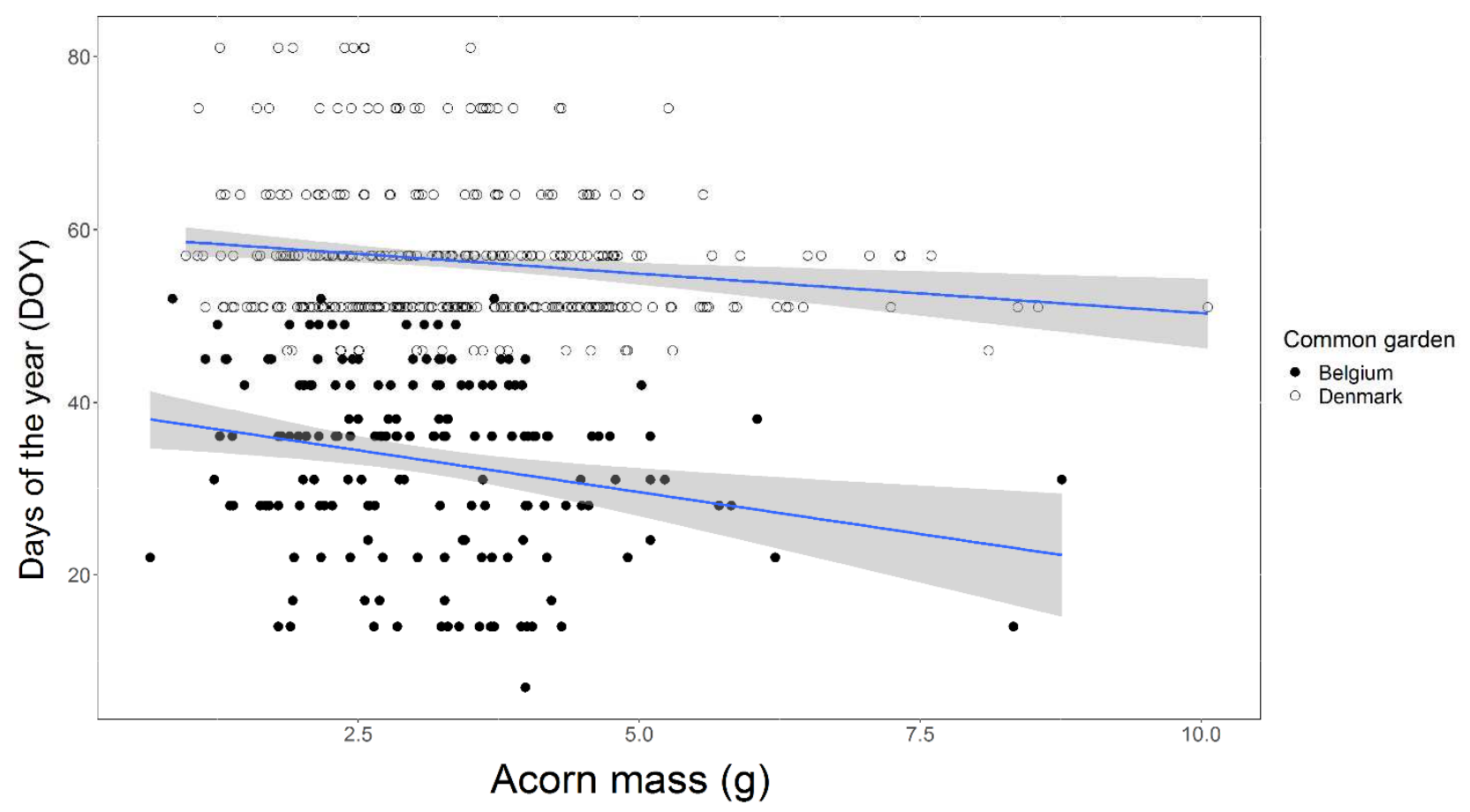

Appendix 6 -- The relationship between acorn mass (g) and bud burst time (DOY-Days of the year, starting on 27 March) of the seedlings in Belgian (BE) and Danish (DK) common garden. 


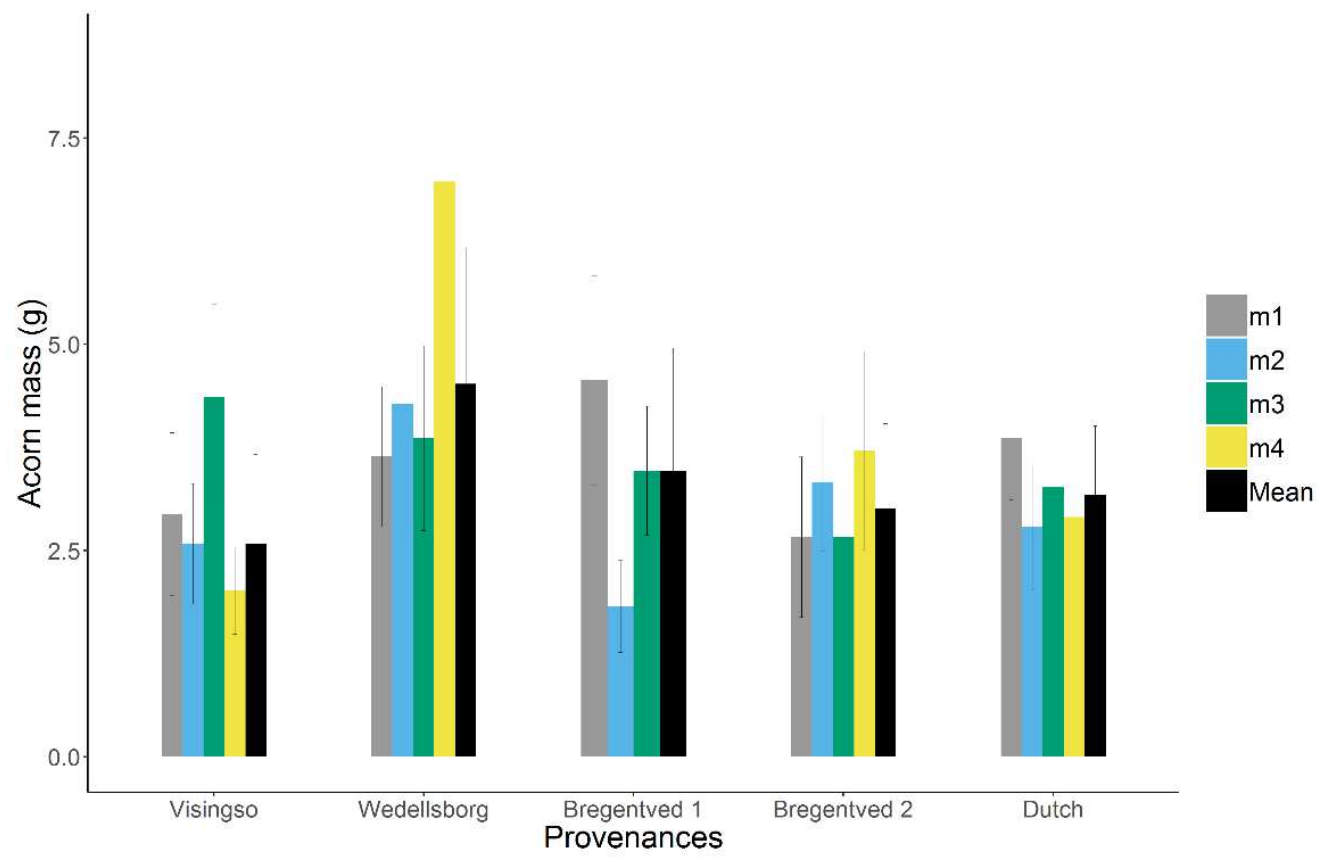

Appendix 7 -- Variability of acorn mass (g) among the provenances. $\mathrm{m} 1, \mathrm{~m} 2, \mathrm{~m} 3$ and $\mathrm{m} 4$ represent the different mother trees in each provenance, and black circles are the mean of all the mother trees. Error bars denote the standard error. 


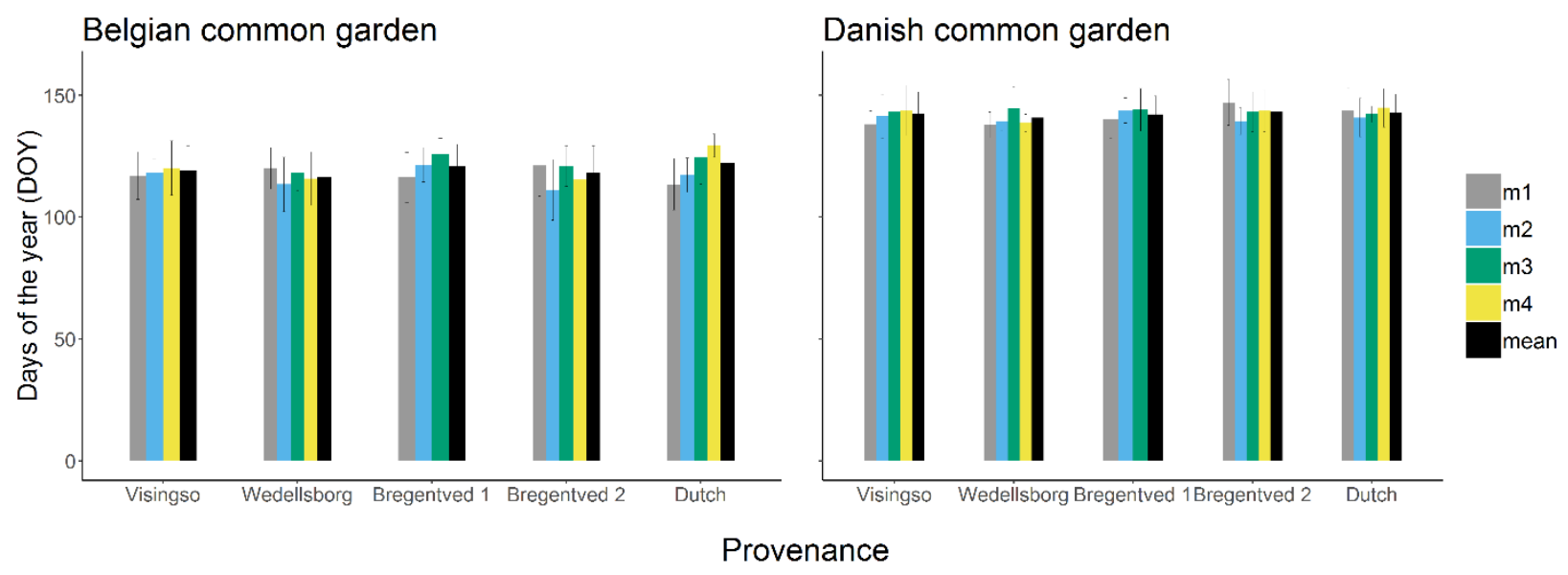

Appendix 8 -- Variability in bud burst time (DOY) among the provenances and mother trees in two common gardens. $\mathrm{m} 1, \mathrm{~m} 2, \mathrm{~m} 3$ and $\mathrm{m} 4$ represent the different mother trees in each provenance, and black bars are the mean of all the mother trees. Error bars denote the standard deviation. 
Appendix 9 -- The variance terms from (Generalized) Linear Mixed Effects models on the bud burst, germination and biomass of the seedlings as a function of common garden, provenances and acorn mass as fixed effects.

\begin{tabular}{|l|l|l|}
\hline Random effects & & \\
\hline Response & Random effect & Variance \\
\hline Bud burst & Tray & 0.0012 \\
\hline Germination & ID (mother tree) & 0.0015 \\
\hline & Tray & 1.1402 \\
\hline Biomass & ID (mother tree) & 0.1458 \\
\hline & Tray & 0.7342 \\
\hline & ID (mother tree) & 0.3718 \\
\hline
\end{tabular}

